\title{
Language Discrimination in the Context of South African Workplace Discrimination Law
}

AM Louw*

\section{P.E.R}

Pioneer in peer-reviewed, open access online law publications

Author

Andre M Louw

Affiliation

Stellenbosch University

South Africa

Email alouw@sun.ac.za

Date Submission

22 September 2021

Date Revised

\section{November 2021}

Date Accepted

3 November 2021

Date published

25 January 2022

\section{Editor Dr N Kilian}

How to cite this article

Louw AM "Language

Discrimination in the Context of

South African Workplace

Discrimination Law" PER / PELJ 2022(25) - DOI

http://dx.doi.org/10.17159/1727-

3781/2022/v25i0a12279

\section{Copyright}

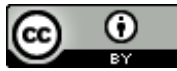

DOI

http://dx.doi.org/10.17159/17273781/2022/v25i0a12279

\begin{abstract}
This contribution considers the role of language as a prohibited ground of unfair discrimination in the workplace in South Africa, an area of law that has been somewhat neglected in the literature to date. It starts by setting out the constitutional and legislative framework for the protection of language rights and the prohibition of unfair discrimination based on language as a listed ground. With a brief comparative reference to other prominent jurisdictions, it then explains the potential ways in which an employer may unfairly discriminate against employees based on language, following which it considers the potential grounds for the justification of language-based discrimination in the workplace. After consideration of the sparse case law on the topic in South Africa, it highlights a few specific issues regarding language and workplace discrimination, before concluding with some thoughts on potential future developments.
\end{abstract}

\section{Keywords}

Language; culture; identity; language rights; unfair discrimination; harassment; justification; inherent requirements of the job defence; reasonable accommodation. 


\section{Introduction and the legal framework}

The Constitution of the Republic of South Africa, 1996 (the Constitution) deals expressly and quite prominently with the recognition of languages and the protection of the choice and use of language. ${ }^{1}$ Section 6 of the Constitution recognises 11 official languages ${ }^{2}$ in the Republic, and contains provisions regarding the state's duties to protect (and, in respect of the indigenous languages, to advance) the use of these languages. ${ }^{3}$ The state's role in the protection and advancement of languages is circumscribed with the proviso that "all official languages must enjoy parity of esteem and must be treated equitably". ${ }^{4}$

Apart from the provisions regarding the recognition, protection and advancement of official (and other ${ }^{5}$ ) languages by the state, the Bill of Rights also entrenches fundamental rights for individuals and groups in respect of their choice and use of language. Apart from the constitutional provisions regarding language in education ${ }^{6}$ (which are beyond the scope of this article), section 30 of the Bill of Rights provides that "Everyone has the right to use the language and to participate in the cultural life of their choice, but no one exercising these rights may do so in a manner inconsistent with any provision of the Bill of Rights". Section 31(1) provides that "Persons belonging to a cultural, religious or linguistic community may not be denied the right, with other members of that community ... to enjoy their culture,

Andre M Louw. BA LLB LLM LLD. Associate Professor, Faculty of Law, Stellenbosch University, South Africa. Email: alouw@sun.ac.za. ORCID: https://orcid.org/00000002-3238-3574.

1 Colon 2002 Yale L \& Pol'y Rev 248 (as quoted in Cavico, Muffler and Mujtaba 2013 JIBCS 26). Historically, the language characteristic has been a key identifier of outsider status and a source of severe prejudice in nations around the world. Section 6(1) of the Constitution of the Republic of South Africa, 1996 (the Constitution) identifies these languages as Sepedi, Sesotho, Setswana, siSwati, Tshivenda, Xitsonga, Afrikaans, English, isiNdebele, isiXhosa and isiZulu.

3 In Re Certification of the Constitution of the Republic of South Africa 19964 SA 744 (CC) para 209. In general, language is a sensitive issue in South Africa.

4 Section 6(4) of the Constitution. For judicial consideration of this provision, see Lourens $v$ Speaker of the National Assembly of Parliament 20162 All SA 340 (SCA).

5 See section 6(5) in respect of the role of the Pan South African Language Board (PANSALB), established in terms of the Pan South African Language Board Act 59 of 1995, as amended by the PANSALB Amendment Act of 1999.

$6 \quad$ Section 29(2) of the Bill of Rights in the Constitution provides as follows: "Everyone has the right to receive education in the official language or languages of their choice in public educational institutions where that education is reasonably practicable. In order to ensure the effective access to, and implementation of, this right, the state must consider all reasonable educational alternatives, including single medium institutions, taking into account- (a) equity; (b) practicability; and (c) the need to redress the results of past racially discriminatory laws and practices." 
practise their religion and use their language". ${ }^{7}$ These rights may also not be exercised in a manner that is inconsistent with a provision of the Bill of Rights. ${ }^{8}$ These language (and cultural) rights are, of course, also bolstered by the freedom of association entrenched in section 18 of the Bill of Rights.

While the state has positive obligations in respect of the protection and promotion of languages, the Constitution also protects the negative aspects of these individual rights to the choice and use of language, "allowing free use by an individual of a language without interference from private or public sources". ${ }^{9}$ The language rights guaranteed in the above provisions are further bolstered by the constitutional guarantee of freedom of expression, ${ }^{10}$ as well as in the equality right. ${ }^{11}$ "Language" is one of the listed grounds contained in section 9(3) of the Bill of Rights, which prohibits direct and indirect unfair discrimination by the state or any other person on any of these grounds. As will be noted from the discussion below, South Africa is relatively unique amongst prominent jurisdictions in respect of the inclusion of language as a listed prohibited ground in its unfair discrimination law. Furthermore, as per the instruction contained in section 9(4), national legislation was enacted to prevent and prohibit unfair discrimination. The Promotion of Equality and Prevention of Unfair Discrimination Act $(P E P U D A)^{12}$ also prohibits unfair discrimination on the grounds of language,$^{13}$ as does the Employment Equity Act (the EEA) ${ }^{14}$ in its section $6(1)$.

In the employment context, therefore, unfair discrimination on the grounds of language in "any employment policy or practice"15 is outlawed by the EEA, while the Labour Relations Act (the LRA) ${ }^{16}$ also makes provision for the protection of employees against dismissal based on unfair discrimination on the grounds of language, which dismissal is marked as automatically unfair. ${ }^{17}$

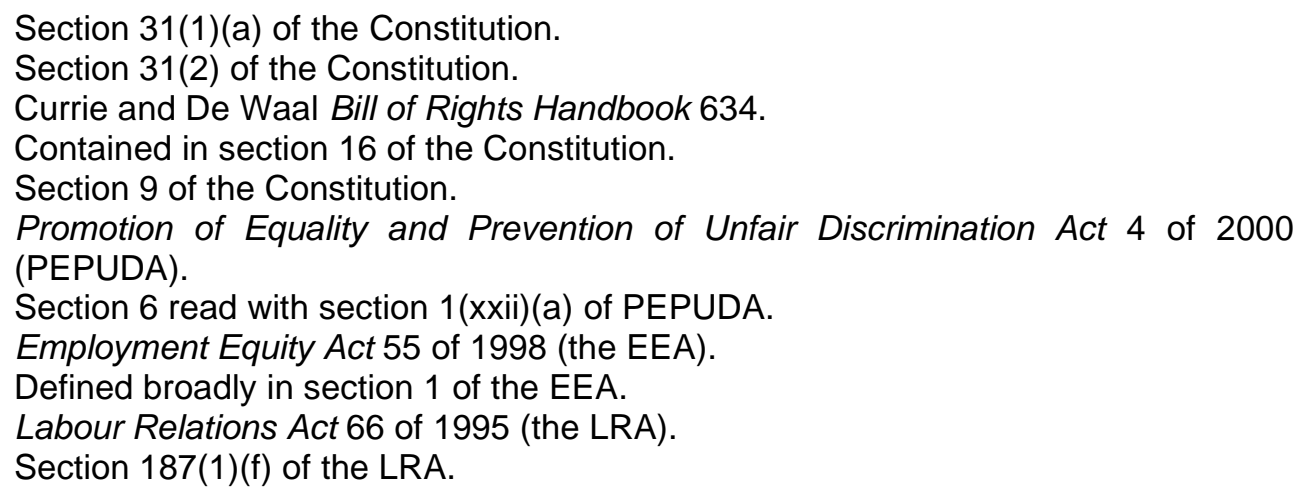


The objective of this piece is to examine more closely issues surrounding language discrimination in the workplace (a topic that has not been widely addressed in the South African literature). It will do so by borrowing, where relevant, from the experience in this regard elsewhere, in the light of the fact that information about language-related policies and practices in South African workplaces is not readily available. The emphasis in the literature has predominantly been on language in education. This piece aims to provide an overview of language in the workplace context, with a focus on unfair discrimination.

In order to interrogate the exact nature, breadth and scope of the prohibition on unfair discrimination in employment on the grounds of language, one needs to first determine the meaning of the term "language" and its role in unfair discrimination law.

\section{2 "Language" and unfair discrimination}

As a rather simplistic point of departure, "language" can be defined as a "system of communication which consists of a set of sounds and written symbols which are used by the people of a particular country or region for talking or writing". ${ }^{18} \mathrm{It}$ is also elsewhere defined as "a body of words and the systems for their use common to a people who are of the same community or nation, the same geographical area, or the same cultural tradition." ${ }^{19}$ Sign language, of course, constitutes a non-spoken form of language that finds special application in the context of the hearing-impaired. ${ }^{20}$

Direct discrimination against a language user on the basis of his or her choice of language may occur in instances where an employer may simply be averse to the use of a particular language in the workplace. But it can be subtler than categorically excluding the use of a particular language, when an employer's policies target not only the choice but also the quality of an employee's use of language. An American Civil Liberties Union (ACLU) guideline document defines language discrimination as follows:

Language discrimination occurs when a person is treated differently because of that person's native language or other characteristics of that person's speech. In an employment situation, for example, an employee may be being subjected to language discrimination if the workplace has a 'speak-English-

\footnotetext{
18 As defined by Collins English Dictionary date unknown https://www.collinsdictionary.com/dictionary/english/language.

19 Dictionary.com date unknown https://www.dictionary.com/browse/language\#.

20 Defined as "any of several visual-gestural systems of communication, especially employing manual gestures, as used among deaf people"; See Dictionary.com date unknown https://www.dictionary.com/browse/sign-language?s=t.
} 
only' policy but the employee's primary language is something other than English. The employee may also be the victim of language discrimination if he or she is treated less favorably than other employees because he or she speaks English with an accent, or if the employee is told he or she does not qualify for a position because of a lack of English proficiency. ${ }^{21}$

From this (and from the broader literature) we see that there are three main types of workplace language policy that may present in practice and form the basis for potential language-based unfair discrimination claims:

a) an exclusionary workplace policy that prescribes the use of only one or more languages in the workplace (and consequently prohibits the use of other languages, such as an employee's native language or mother tongue);

b) a workplace policy that requires a specific level of language proficiency in a certain language in order to get and do the job; and

c) workplace policies or practices aimed at prohibiting (or which treat in a prejudicial manner) aspects of an employee's workplace language use (e.g. certain accents, dialects or speech patterns).

In the light of the South African constitutional framework, all three such forms of workplace policies implicate constitutionally-entrenched language rights. They impact on the rights to choose, to use and to enjoy a language (and, in the case of the first type of policy, possibly the freedom to associate with other users of that language). At this point it just bears mentioning, however, that the prohibition of discrimination on the basis of language in terms of the EEA and section 9 of the Constitution is distinct from the protection of language rights provided for by the above-quoted sections 30 and 31(1) of the Bill of Rights. As Langa CJ explained in MEC for Education: Kwazulu-Natal $v$ Pillay (hereafter Pillay) (there in the context of religion and culture rather than language), these rights may overlap. ${ }^{22}$ In the workplace context, a claim of unfair discrimination based on language under the EEA must proceed with due regard for the question of unfairness of any proven discrimination and possible justification by the employer.

The importance of language, specifically in the context of unfair discrimination, is broader than mere language as a form of communication. As one definition of language observes, it is "a system of conventional spoken, manual, or written symbols by means of which human beings, as

21 ACLU Northern California Language Discrimination.

22 MEC for Education: Kwazulu-Natal v Pillay 20081 SA 474 (CC) (hereafter Pillay) para 46. 
members of a social group and participants in its culture, express themselves. The functions of language include communication, the expression of identity, play, imaginative expression, and emotional release." 23 Especially in a linguistically and culturally diverse society, there are clear and potent links between language and identity. ${ }^{24}$

Moseneke DCJ, in the well-known Ermelo High School language policy case, recognised the role of language (in that context, the indigenous African languages) as "vehicles for expressing cultural identity". ${ }^{25}$ This link between language and identity pertinently raises issues of dignity, which is so central to South Africa's unfair discrimination law. The Supreme Court of Appeal (the SCA), ${ }^{26}$ in recognising that identity forms part of an individual's "protectable variety of personal rights" under the common law (which also include privacy and dignity), relied on an exposition of the role of dignity as entrenched in section 10 of the Bill of Rights to include the individual's sense of self-worth but also the public's estimation of the worth of such an individual. ${ }^{27}$ And in the context of international human rights law it has been observed that "[s]ince language is central to identity, one's freedom to use one's language is seen as 'inherent' in the 'dignity of the human person', and thus falls within the ambit of human rights law."28

The potential impact that unfair discrimination on the grounds of language may have on a claimant's dignity accounts for the inclusion of language as a listed prohibited ground in both the South African constitutional equality right as well as the EEA. ${ }^{29}$

Unfair discrimination in South African workplaces is adjudicated in terms of the test formulated in Harksen $v$ Lane. ${ }^{30}$ There, the Constitutional Court formulated a test which proceeds, firstly, to determine whether there was differentiation in respect of the claimant compared to others.

23 Britannica date unknown https://www.britannica.com/topic/language.

24 As the US Court of Appeals observed in Gutierrez v Municipal Court of Southeast Judicial District County of Los Angeles 838 F 2d 1031 (9th Cir 1988) para 18: "Because language and accents are identifying characteristics, rules which have a negative effect on bilinguals, individuals with accents, or non-English speakers, may be mere pretexts for intentional national origin discrimination." Also see Ainsworth 2010 Seattle J for Soc Just 245. Head of Department: Mpumalanga Department of Education v Hoërskool Ermelo 20102 SA 415 (CC) para 48. In Grütter v Lombard 20074 SA 89 (SCA). O'Regan J in Khumalo v Holomisa 20025 SA 401 (CC) para 27 (as quoted in Grütter $v$ Lombard 20074 SA 89 (SCA) para 12).

28 Paz 2014 EJIL 474.

29 See Harksen $v$ Lane 19981 SA 300 (CC) para 49.

30 Harksen $v$ Lane 19981 SA 300 (CC). 
"Differentiation" may be in treatment (and constitute direct discrimination) or in effect of what is a facially neutral policy or practice which has a disproportionate effect on a certain group (and constitute indirect discrimination). Differentiation itself is not outlawed; differentiation which constitutes discrimination (and is unfair) is. The determination of whether differentiation constitutes discrimination will depend on the reason for the differentiation. If it is on one of the listed grounds in section 9(3) of the Bill of Rights (or on one or more of the listed grounds in section 6(1) of the EEA) it is deemed to be discrimination, because of the potential of differentiation on such grounds to impact prejudicially on the dignity of the complainant, and in terms of section 9(5) of the Bill of Rights it is presumed to be unfair. If the employer fails to prove the fairness of the discrimination it must be determined whether the limitation of the claimant's equality right is a reasonable and justifiable limitation in terms of section 36 of the Bill of Rights (the limitations clause). Section 11(1) of the EEA provides that when discrimination on a listed ground is shown, the employer may justify such discrimination on the grounds that it is rational and not unfair, or otherwise justifiable. According to section 6(2) of the EEA it is not unfair discrimination to "distinguish, exclude or prefer any person on the basis of an inherent requirement of a job". Section 4 in the text below will specifically focus on the justification of unfair discrimination based on language.

In the light of the role of language in expressing and forming identity, exclusionary language policies in the workplace may not only serve to impact on the dignity of individual complainants but may also serve to act in a divisive way to exclude individuals and groups and to create an alienating workplace or corporate culture which is anathema to the promotion of diversity. Language choice and use serves as an instrument to express solidarity and "sameness" and to build cohesion between group members who share cultural, ethnic and social origins. An employer who seeks to exclude the use of one or more languages may be fostering a culture of workplace hostility and inter-group prejudice. In the United States it has been the experience that the application of "English-only" workplace policies based on employers' stated intention to promote workplace harmony through the means of enforced homogeneity between different ethnic groups has in a number of cases in fact achieved the opposite, with workplaces becoming more ethnically polarised and tense as a result. ${ }^{31}$ The English language idiom "to speak the same language as [someone else]" refers to persons sharing the same beliefs, attitudes, etc. When employers try to force all employees to speak the same language, however, the effects

31 Ainsworth 2010 Seattle J for Soc Just 248. 
of such policies may often lead to the creation of disharmony, suspicion and conflict between groups.

The role and importance that an employer or prospective employer places on the use of language may implicate grounds of potential discrimination beyond merely language (as a form of communication in the workplace), and may expose underlying prejudices seemingly divorced from language per se. It has been observed that language is one of the elements of culture, and that an important relationship exists between culture and language, leaving "communication and culture ... inseparable". ${ }^{32}$ Apart from culture (a listed ground in the constitutional equality right as well as in section 6 of the EEA) other grounds may also feature. Several jurisdictions recognise that discrimination on the basis of language or relating to language may implicate other prohibited grounds of unfair discrimination.

As observed in Canadian case law, there is "almost inevitably a link between the language we speak or the accent with which we speak a particular language on the one hand, and our ancestry, ethnic origin or place of origin on the other." 33 In Canada, language-based discrimination may implicate unfair discrimination on several grounds, including ancestry, ethnic origin, place of origin and race. ${ }^{34}$

In New Zealand it is recognised that employer conduct or policies which target employees' use of a first language may constitute unlawful discrimination on the grounds of race, ethnic or national origin under the Human Rights Act, 1993. ${ }^{35}$

In the United States of America (USA) it is recognised that discrimination based on language may be a form of national origin discrimination, which is outlawed under Title VII of the Civil Rights Act of 1964 (Title VII). ${ }^{36}$ The USA has seen a relative proliferation of cases involving complaints of national

32 Ackerman Cross-Cultural Negotiations, as quoted by Prinsloo and Huysamen 2018 LDD 37.

33 Espinoza v Coldmatic Refrigeration of Canada Inc et al (Ont Bd of Inq) (unreported) inquiry file number 93-0043 and decision 95-013 of 31 March 1995. As has been observed: "Language proficiency can be seen as related to (or a consequence of) ancestry and place of origin, because a person's knowledge of a language depends on where he or she grew up."; Munro 2003 TESL Canada Journal 42. For example, the Ontario Human Rights Code does not specifically prohibit discrimination on the grounds of language; see the Ontario Human Rights Commission Policy on Discrimination and Language 4. New Zealand Human Rights Commission date unknown https://www.hrc.co.nz/howwe-can-help/faqs/english-language-only-workplace/. 
origin discrimination, which often involve language ability, with one source quoting a 76\% increase in such cases between 1997 and 2011 (when more than 11800 such cases were filed with the US Equal Employment Opportunities Commission). ${ }^{37}$

In Australia it is recognised that discrimination on the grounds of language may constitute prohibited unfair discrimination on the grounds of race in terms of the Racial Discrimination Act of 1975, as language may be directly linked to ethnic background. ${ }^{38}$

In the United Kingdom (UK), language discrimination may constitute direct or indirect discrimination on the grounds of race (which encompasses nationality, colour and ethnic origins) in terms of the Equality Act, 2010.

In a country as (linguistically and otherwise) diverse as South Africa, and where especially ethnic and cultural diversity carries with it the baggage of such a troubled past of unfair treatment and the exclusion of others, it is clear that language links closely to other listed grounds of unfair discrimination which, even if one accepts the link between language and (identity and) dignity explored above, are even more easily recognisable as suspect grounds for the disparate treatment of individuals and groups. Apart from ancestry and ethnic origin ${ }^{39}$ (which are invariably tied up with race and colour), language is also a product of (and links closely to) cultures, and discrimination on the grounds of language may frequently also involve discrimination linked to the culture of an individual or group of individuals. All of these involve listed grounds, but discrimination based on language (particularly in respect of accents, dialects and speech patterns) may also implicate unlisted or potential arbitrary grounds ${ }^{40}$ (for example, the use of

\footnotetext{
37 Foy $2021 \quad$ https://www.insurancejournal.com/news/national/2012/12/04/ 272632.htm\#.

38 Australian Human Rights Commission date unknown https://www.humanrights.gov.au/quick-guide/12060.

$39 \quad$ Although it should be noted that this link between language and ethnic origin is not necessarily always present for an individual; See Ainsworth 2010 Seattle $J$ for Soc Just 245.

40 With due regard for the fact that courts need to be circumspect in recognising arbitrary grounds (in terms of section 6(1) of the EEA) for the purposes of finding unfair discrimination, and with reference to the "narrow" approach of the Harksen test and proper consideration of the impact on dignity-implications of the relevant ground averred in any given case; See Garbers 2019 CLL. The narrow approach to the recognition of arbitrary grounds requires that any claimed arbitrary ground of discrimination must have the potential to impair the dignity of a person (or must have a comparably serious effect) under the Harksen standard, rather than the "broad compass" approach followed in several judgments which defined arbitrary grounds as any ground characterised by capriciousness. The narrow approach was endorsed
} 
"prison lingo" by ex-offenders, or where the employer's complaint against the employee's use or quality of language may be more akin to a form of appearance discrimination - where linguistic profiling, ${ }^{41}$ accompanied by ethnocentrism or classism, occurs in the process of formulating a profile of the "ideal candidate" for the job who is not only physically attractive and well-groomed, but also "well-spoken").

\section{Forms of potential unfair discrimination based on language}

There are various forms of employer conduct or policies which may occur in the workplace and have an unfairly discriminatory effect on employees. First, one can distinguish different discrete forms of language-related policies that are aimed specifically at controlling the use of language in the workplace. Secondly, employer conduct in response to the choice (or quality of use) of language by employees may constitute unfair discrimination.

\subsection{Language policies}

\subsubsection{Compulsory use of one language in the workplace}

Language discrimination may take a variety of forms in respect of suspect employer conduct and policies. One such form that is often encountered across jurisdictions is a "speak-English-only" policy in the workplace, whereby employees are prohibited from speaking in their native tongue by means of a rule requiring them to speak only English. This is probably the most blatant form of workplace policy affecting language, by dint of its exclusionary nature and clearly prejudicial impact on second-language speakers of the preferred language. Such rules are, not surprisingly, controversial, as one commentator in the American context has warned: "Courts should be inherently suspicious of English-only rules because of their propensity to act as a cloak for discrimination".42 These rules are vulnerable to attack in the United States as constituting indirect (disparate impact) unfair discrimination on the basis of national origin or race. ${ }^{43}$

by the Labour Appeal Court (the LAC) in Naidoo $v$ Parliament of the Republic of South Africa 202010 BLLR 1009 (LAC).

Which can be defined as the practice of using speech characteristics or dialect to identify a speaker's race or religion or social class.

42 Stoter 2008 Vill L Rev 597 (as quoted in Cavico, Muffler and Mujtaba 2013 JIBCS 26).

As explained by Ainsworth 2010 Seattle J for Soc Just 236-237. 
The South African Constitution in section 30 provides that "[e]veryone has the right to use the language ... of their choice". Section 9 , the equality right, and section 6(1) of the EEA prohibit unfair discrimination on the grounds of language. This raises the question as to an employee's entitlement to use the language of their choice in the workplace (especially in the face of such an exclusionary employer policy).

Employers are entitled to formulate workplace rules and to discipline employees for misconduct in failing to obey such rules. The Code of Good Practice: Dismissal (Schedule 8 of the LRA) provides that a fair dismissal for misconduct requires contravention of a rule that is valid. Generally, a rule should be "capable of justification by reference to the nature and requirements of the employer's business". ${ }^{44}$ The common law also requires of employees to obey lawful instructions. A workplace language policy such as an "English-only" rule may be justified for a number of reasons, including workplace safety, increasing productivity and efficiency. Such a rule could be reasonable and justifiable, which would mean that employees may not be able to claim a right to speak another language in the workplace. The unfair discrimination provisions - and, specifically, the status of language as a listed ground - simply mean that the employer may not unfairly discriminate against such an employee on the basis of his or her choice or use of language. Accordingly, any workplace policy that may impact on such an employee's choice and use of language may be justifiable in terms of the inherent requirements of the job (section 6(2) of the EEA ${ }^{45}$ or may be shown to be rational, not unfair or otherwise justifiable by the employer. ${ }^{46}$

It is submitted, however, that in the light of the section 30 constitutional right, an "English-only" rule (or one that similarly prescribes the use of only one language, thus banning the use of all others) may be treated with even more suspicion in the South African context. ${ }^{47}$ For bilingual or multilingual persons the constitutionally-protected choice of which language to use is deserving of protection by law. ${ }^{48}$ This issue of an employee's choice to use a language

\footnotetext{
$44 \quad$ Van Niekerk and Smit Law@Work 282.

45 See discussion in section 3 below.

46 Section 11(1) of the EEA.

47 Ainsworth explains that some US courts have been reluctant to find "English-only" rules in the workplace to be unfairly discriminatory in cases involving bilingual minority claimants; See Ainsworth 2010 Seattle $J$ for Soc Just 238-239. It is unclear whether a South African claimant would face a similar approach by a court, in the light of the fact that the choice and use of language is constitutionally entrenched in section 30 of the Constitution. In respect of the issue of choice, see Pillay paras 63-66.
} 
in the face of an exclusionary workplace policy (such as an "English-only" rule) has not come before the courts to date.

\subsubsection{Language proficiency policies}

The relevant employer policy or practice may also be less blatantly exclusionary in nature (i.e. by not completely banning the use of any one or more languages in the workplace). The most prevalent example is a policy or hiring decision that requires a certain level of proficiency in any given language (invariably English). Such policies have been implicated in South African case law to date, involving requirements of proficiency in English 49 (for a foreign-born university lecturer) and Afrikaans (for a prospective school principal of an Afrikaans-medium school). ${ }^{50}$ Language proficiency policies may serve to posit language as a proxy for other grounds of potential (indirect) unfair discrimination, but they may also be more easily justifiable. Such policies will be examined further below in the context of the employer's "inherent requirements of the job" defence. ${ }^{51}$

\subsubsection{More neutral language-related policies}

It also bears noting that employer policies and practices that may seem facially "language-neutral" or unrelated to language may, in fact, constitute unfair discrimination on the grounds of language. Appearance and grooming-related rules or job requirements (such as "excellent verbal and written communication skills", "a professional demeanour" or "ability to interact with up-market clients" in a job advertisement) may point to an implicit preference for candidates with a particular language proficiency and linguistic (and social) heritage (for example, an employer who might under the guise of a requirement of "professionalism" attempt to avoid the use of so-called "Cape coloured language" in the workplace or in employees' interaction with customers, or admonishments to employees to speak or write "proper English").

\subsection{Employees' choice and (quality of) use of language}

Apart from the variety of possible forms of suspect employer conduct which may implicate language, potential language-based discrimination may involve a variety of aspects of language choice and (quality of) use by an employee or applicant. The first, of course, is the choice of language. An

\footnotetext{
$49 \quad$ Stojce $v$ University of KwaZulu-Natal 20073 BLLR 246 (LC).

50 Stokwe $v$ Member of the Executive Council, Department of Education Eastern Cape Province 20058 BLLR 822 (LC).

51 Section $6(2)$ of the EEA and see discussion in section 3 in the text below.
} 
employer may react with unlawful conduct based on prejudice regarding the choice of language of the employee or applicant (e.g. where the employer may be averse to the use of Afrikaans or of an indigenous African language). As already mentioned, rules prohibiting the use of any one language may be problematic in the light of the constitutional protection of the right to use the language of one's choice.

Secondly, as mentioned above, an employer may demand a certain level of proficiency in a language. This may be justified in respect of operational and job requirements (including safety in the workplace), but could also indicate indirect discrimination on other grounds (such as race or sex, where an employee's level of education may impact on the size of his or her vocabulary and syntax in respect of the relevant language)..$^{52}$

Thirdly, more nuanced aspects of language use may be involved; for example, an employer's aversion to certain accents or dialects for ulterior reasons and based on underlying prejudice against certain groups. This is problematic from the perspective of unfair discrimination, as a person's accent may very well constitute an immutable characteristic. It is widely recognised that "the acquisition of a second language after early childhood inevitably results in speech that differs from that of native speakers, largely because knowledge of the sound system of the first language influences the perception and production of the phonetic patterns of the second." ${ }^{53}$ As a result, discrimination based on a person's accent may implicate such a person's social origin (a listed prohibited ground of unfair discrimination in both the Constitution and the EEA). Linguistic profiling of speakers (by employers and customers alike) is fraught with risks. ${ }^{54}$ "Accentism" or "accent bias" may be indicative of underlying prejudice and discriminatory attitudes on the part of employers, ${ }^{55}$ which may implicate other prohibited grounds of discrimination (such as race, ethnic origin and culture). Linguistic profiling may also implicate an employee's sexual orientation when perceptions of femininity or masculinity through their use of language (or pronunciation and speech patterns) are used to covertly or overtly classify employees as gay or lesbian, for example. ${ }^{56}$

\footnotetext{
52 Also see the discussion in section 4.2 below in respect of language proficiency testing.

$53 \quad$ Munro 2003 TESL Canada Journal 38.

54 See Baugh "Linguistic Profiling and Discrimination".

55 See Schoeman 2018 Corporate Report 4.

56 Munson 2007 Language and Speech.
} 


\section{Language and the justification of unfair discrimination}

Language ${ }^{57}$ is one of the listed grounds of unfair discrimination that often may implicate the "inherent requirements of the job" defence ${ }^{58}$ for employers faced with unfair discrimination claims. But here employers must tread with care, as the courts prefer a narrow interpretation of inherent job requirements. While recognising a measure of employer prerogative in designing job descriptions, the approach by the courts is strict. ${ }^{59}$ Inherent requirements were defined as follows by the SCA in Department of Correctional Services $v$ Police and Prisons Civil Rights Union (hereafter POPCRU: :00

An inherent requirement of a job has been interpreted to mean 'a permanent attribute or quality forming an ... essential element ... and an indispensable attribute which must relate in an inescapable way to the performing of a job'.

More recently, Murphy AJA in the Labour Appeal Court (the LAC) considered the inherent requirements defence in TDF Network Africa (Pty) $L t d v$ Faris (hereafter Faris), a case involving claimed unfair discrimination on the basis of religion: 61

The test for whether a requirement is inherent or inescapable in the performance of the job is essentially a proportionality enquiry. Considering the exceptional nature of the defence, the requirement must be strictly construed. A mere legitimate commercial rationale will not be enough. In general, the requirement must be rationally connected to the performance of the job. This means that the requirement should have been adopted in a genuine and good faith belief that it was necessary to the fulfilment of a legitimate work-related purpose and must be reasonably necessary to the accomplishment of that purpose. However, even if that is shown, the enquiry does not end there. In addition, the employer bears the burden of proving that it is impossible to accommodate the individual employee without imposing undue hardship or insurmountable operational difficulty. ${ }^{62}$

In the present context, the relevant requirement would depend on the relevant form of workplace language policy that is at issue. It could relate to a policy requiring a certain standard of language proficiency (for example,

$57 \quad$ This section will focus on the inherent requirements of the job defence as contained in section 6(2) of the EEA and section 187(2) of the LRA. It will not consider the possibility of whether affirmative action (as mentioned in section 6(2) of the EEA) could possibly be used as a justification by an employer facing a language discrimination claim.

58 Section $6(2)$ of the EEA.

59 See Grogan Employment Rights 257-262.

60 Department of Correctional Services v Police and Prisons Civil Rights Union 2013 34 ILJ 1375 (SCA) (hereafter POPCRU) para 21.

$61 \quad$ Network Africa (Pty) Ltd v Faris 20192 BLLR 127 (LAC) (hereafter Faris).

$62 \quad$ Faris paras $37-38$. 
in English), or it could relate to a policy that requires the use of only one language in the workplace (for example, an "English-only" policy).

\title{
4.1 Language proficiency policies
}

A language proficiency requirement would have to relate to a real and bona fide need for the required level of proficiency in performing the job to the applicable standard, and should not be based on stereotyping of the group to which the employee belongs. ${ }^{63}$ We may possibly take some guidance in respect of determining the parameters for the inherent requirements defence in the context of language from what the SCA said in the context of claimed unfair discrimination on other listed grounds in POPCRU:

\begin{abstract}
A policy is not justified if it restricts a practice of religious belief - and by necessary extension, a cultural belief - that does not affect an employee's ability to perform his duties, nor jeopardise the safety of the public or other employees nor cause undue hardship to the employer in a practical sense. ${ }^{64}$
\end{abstract}

As Bernard observes, the employer in that case (the Department of Correctional Services) "was unable to illustrate a rational connection between the purported purpose of the discrimination and the measure taken, nor was it shown that the department would suffer an unreasonable burden if it had exempted the respondents."65 It can be noted that the mention of public safety and the safety of employees in POPCRU is reminiscent of the same factor which forms part of the business necessity test applied by American courts in testing English-only workplace policies. ${ }^{66}$

Obvious examples where inherent requirements would justify a requirement of proficiency 67 in English would be in the case of an emergency services 9-1-1 call operator, an admissions clerk in a hospital emergency room, an airline pilot or air traffic controller (who operates in airspace where English language proficiency is required by the International Civil Aviation Organisation), or a radio DJ serving a primarily English-speaking audience.

\footnotetext{
63 IMATU v City of Cape Town 200526 ILJ 1404 (LC) 1141A.

64 POPCRU para 25.

65 Bernard 2014 PELJ 2879.

66 See discussion elsewhere in this piece.

67 Which I will define here as a comprehensive English vocabulary, an acceptable level of grammar and sufficiently clear pronunciation to enable clear and unambiguous communication in the English language. English proficiency tests are widely employed in respect of university admissions in various jurisdictions, with the predominant international tests being the TOEFL (Test of English as a Foreign Language) and IELTS (International English Language Testing System).
} 
In De Bruyn v Metorex (hereafter De Bruyn) ${ }^{68}$ the LAC accepted the inherent requirements of the job defence in the context of the dismissal for operational requirements of an employee of a Chinese-owned mining company operating in Africa who had been replaced by a Chinese-speaking employee. Relying on the test as formulated in Faris, the court held that "[i]n respect of the position [the applicant] was contending for, namely acting deputy CEO, the ability to speak Chinese had essentially become an inherent requirement of the job in order to facilitate direct communications with the general managers of the mines, Chinese shareholders, and with Chinese financial institutions." ${ }^{69}$ The court held that the retention of the applicant in the circumstances would have imposed undue hardship and insurmountable difficulties on the employer.

Testing applicants for appointment or promotion (access to a job) in respect of language proficiency should also be across-the-board and not be selective in respect of only certain applicants. In such a case the application of the policy could of course be indirectly discriminatory on other grounds (such as race). Workplace testing itself is, of course, regulated by the EEA. ${ }^{70}$

Also, a blanket ban in cases of a lack of required proficiency may be inappropriate and open the employer to potential claims of unfair discrimination where employees in different sections of the workplace or organisation of the employer are measured against the same standard. (For example, language proficiency would be more important in a customer service environment than it would be in respect of warehouse staff. $)^{71}$ Such a blanket ban which fails to take into account the real need for a certain level of language proficiency on the part of differently-placed employees could be deemed to be based on "inaccurate, generalised assumptions about [language users] as a class or group and as such [may be] open to the criticism of being disproportionate." ${ }^{72} \mathrm{~A}$ blanket ban approach could possibly be deemed to be irrational (depending on the nature of the workplace and its constitutive elements and the nature of the relevant job(s)), which would

68 De Bruyn v Metorex (Pty) Ltd 202110 BLLR 979 (LAC) (hereafter De Bruyn). See further discussion of this case in section 4 below.

69 De Bruyn para 38 of the judgment.

70 See section 5.2 below.

71 The dangers of a "blanket ban" approach by employers in the context of the inherent requirements of the job defence (relating to a claim of unfair discrimination on the grounds of disability) are illustrated in IMATU v City of Cape Town 200526 ILJ 1404 (LC); and in Jansen van Vuuren v SA Airways (Pty) Ltd 201334 ILJ 1749 (LC) and South African Airways (Pty) Ltd v GJJVV 20148 BLLR 748 (LAC) (in the context of retirement age).

72 IMATU v City of Cape Town 200526 ILJ 1404 (LC) para 96 (expressed there in the context of insulin-dependent diabetics as a group). 
preclude an employer from proving fairness of discrimination in terms of section 11(1)(b) of the EEA.

It bears noting that courts have frowned upon employers' reliance on customer preferences based on prejudice, stereotyping and stigma ${ }^{73}$ when employing the inherent requirements defence (which may be relevant in respect of customer complaints relating to employees' choice and use of language, or of specific accents, dialects or speech patterns). In the same breath it should be said that genuine customer preferences which are not based on prejudice, allied with an employer's strategic targeting of a specific group of consumers, may serve to determine workplace policies in respect of language and language-based hiring decisions. For example, in 2019 Finbond mutual bank launched an online banking service (Finbond Platinum) which specifically targets the Afrikaans-speaking banking market in South Africa. According to its web site, the bank's vision is to be "the leading Afrikaans bank in South Africa", and its purpose is to "improve the quality of life of our clients by offering modern, inclusive banking products and services in Afrikaans."74 In such an endeavour it is to be expected that the employer will be led in certain hiring decisions to impose an Afrikaans proficiency policy and requirements (for example, in respect of call centre and other customer service personnel). It is interesting to speculate whether any possible future legal challenge to such policies and practices in the form of an unfair discrimination claim by an unsuccessful applicant based on language could be met by an inherent requirement of the job defence (especially bearing in mind the afore-mentioned observation in Faris that the defence must be strictly construed, and that a "mere legitimate commercial rationale will not be enough" for an employer to justify unfair discrimination). ${ }^{75}$

In some jurisdictions and sectors, it is possible that a certain level of language proficiency may be prescribed by means of legislation. In the UK the Immigration Act, $2016^{76}$ contains "fluency" requirements in respect of all employees of public authorities in "customer-facing roles"77 in respect of English (and in Wales, in respect of English and Welsh). Apart from the

See Hoffmann $v$ South African Airways 20011 SA 1 (CC) (in the context of discrimination on the basis of HIV status); Grogan Employment Rights 258-260.

74 Translated from the Afrikaans text, Finbond date unknown https://www.finbondplatinum.co.za/vision-and-mission.

See the text to footnote 61 above.

76 Immigration Act, 2016 Part 7: Language Requirements for Public Sector Workers.

77 Defined in section 77 of the Immigration Act, 2016 as "a person who, as a regular and intrinsic part of the person's role, is required to speak to members of the public in English." 
rather opaque definition of "fluency" in English in this particular legislation ${ }^{78}$ and the obvious potential equality and non-discrimination implications, ${ }^{79}$ such legislative prescriptions would of course provide justification for affected employers in setting workplace language proficiency policies, similar to immigration rules relating to the need for foreign nationals to obtain a work permit in order to be lawfully employed. Few such language proficiency requirements currently exist in South Africa in terms of legislation which directly prescribes choice, use or proficiency of language in workplaces ${ }^{80}$ (apart from national government departments covered by the Use of Official Languages Act, 2012) ${ }^{81}$. However, language-related legislative prescriptions may in certain circumstances affect an employer's business and provision of services and thus indirectly impact on hiring decisions as well as workplace policies regarding both language proficiency and language use by employees. An example is the National Credit Act, 2005. ${ }^{82}$ Section $63(1)$ of the Act provides as follows:

A consumer has a right to receive any document that is required in terms of this Act in an official language that the consumer reads or understands, to the extent that is reasonable having regard to usage, practicality, expense, regional circumstances and the balance of the needs and preferences of the population ordinarily served by the person required to deliver that document.

Registered credit providers covered by the Act may therefore be forced to provide documentation and customer service (e.g. in the form of call centre assistance) in a particular official language or languages, which would necessitate such employers hiring employees proficient in such language or languages. ${ }^{83}$ In such cases, where a hiring decision or language proficiency policy necessitated by compliance with relevant legislation may be challenged by means of an unfair discrimination claim, it is expected that it would be much easier for an employer to justify such a practice or policy

See the Code of Practice on the English Language Requirements for Public Sector Workers in Part 7 of the Immigration Act, 2016.

79 See Milsom $2016 \mathrm{https}$ ://www.cloisters.com/the-immigration-act-and-the-fluencyduty-for-public-sector-workers-speaking-in-tongues/.

See, for example, Regulation 61.1.07 (English language proficiency required in respect of pilot licensing) of the Civil Aviation Regulations, 2011 (GN R425 in GG 35398 of 1 June 2012) published in terms of the Civil Aviation Act 13 of 2009. Also see para 8 of the Revised Policy for the Minimum Requirements for Teacher Education Qualifications (GN 111 in GG 38487 of 19 February 2015), published in terms of the National Qualifications Framework Act 67 of 2008.

81 Use of Official Languages Act 12 of 2012.

$82 \quad$ National Credit Act 34 of 2005.

83 For example, major bank FNB's language policy identifies English, Afrikaans, isiZulu and Setswana as its official languages for the provision of customer documentation and customer service assistance - see FNB date unknown https://www.rmbprivatebank.com/downloads/RMBPrivateBank/evolve/legal/FirstRa ndLanguageProposal.pdf. 
as an inherent job requirement than in the above-mentioned example, where the policy or practice would be implemented in furtherance of an internal, organisation-specific commercial rationale or strategic objective of the employer.

\subsection{Exclusionary policies}

In the context of "English-only" workplace policies in the USA it has been observed that "some employers are rightfully concerned that the workplace will become deluged with a variety of languages, thereby impeding safety, efficiency, harmony, productivity, and possibly alienate a customer base."84 There may very well be a variety of reasons - some justifiable - for an employer to seek uniformity in respect of language usage in the workplace, but such reasons will always be subject to strict judicial scrutiny in the face of claims of unfair discrimination (in the USA the courts and legislatures have fashioned a strict "business necessity" standard for such "Englishonly" policies). As indicated above, the LAC in Faris held that a "mere legitimate commercial rationale will not be enough" to qualify a requirement as inherent to the job. Whether the restrictive effect on second-language speakers would be justified by considerations of safety, efficiency, harmony, productivity and customer preferences would have to be adjudicated in every case with due regard for the proportionality enquiry identified in Faris, as well as for the parameters of reasonable accommodation. In the USA it has been argued that safety and efficiency may very well suffer in the face of a compulsory "speak English only" policy (and that, for example, Latino employees may be better placed to ensure safety in the workplace and may work more efficiently when allowed to converse in their mother tongue), and also that such policies may instead of creating workplace harmony in fact lead to polarisation and tensions in the workplace between different ethnic groups. ${ }^{85}$ Similar arguments can likely be made in the South African context.

\section{Case law}

South African case law on language-based discrimination in the workplace is sparse. Apart from a recent LAC judgment which dealt briefly with a language-related claim, ${ }^{86}$ to date only two cases have been reported in the Labour Court, both heard by the same judge in the same court. Neither has

Cavico, Muffler and Mujtaba 2013 JIBCS 24.

Ainsworth 2010 Seattle J for Soc Just 233.

See discussion in the text below at the end of this section. 
provided real guidance on the approach the courts should take in respect of language-based discrimination.

The first case, Stokwe v Member of the Executive Council, Department of Education Eastern Cape Province (hereafter Stokwe), ${ }^{87}$ involved the nonappointment of an African female applicant to the post of principal of an Afrikaans-language school in the Eastern Cape. The applicant had been recommended by an interview committee, subject to confirmation by the school's governing body (the SGB), who would make a recommendation to the relevant MEC of the provincial Department of Education. When the SGB eventually met to consider the appointment, "die taalkwessie"88 apparently reared its head, as "[o]n seeing that the applicant bore an African name, members of the SGB raised their own concern about her ability to speak Afrikaans". ${ }^{89}$ The SGB's recommendation was to change the order of preference of the candidates as recommended by the interview committee (with the applicant dropped to second place in the ranking). An education department official then informed the applicant that an "independent review panel" had been established to review the SGB's recommendation. The review panel consisted of three white male Afrikaans-speaking principals of other primary schools in the area. For the applicant it was not a happy experience: The review panel insisted that the interview should proceed in Afrikaans, and the applicant refused to speak Afrikaans. ${ }^{90}$ She defended her competency in Afrikaans and argued that Afrikaans proficiency was not a requirement for anyone appointed to the post of principal. ${ }^{91}$

Following the applicant's non-appointment (she apparently never received news of her rejection for the post) she brought a claim based on several substantive and procedural grounds. Pertinent for current purposes is her claim for unfair discrimination based on section 9 of the Bill of Rights. ${ }^{92}$ The judgment of the court does not expressly record the exact alleged grounds of unfair discrimination, but the court, by way of Pillay $\mathrm{J}$, found that both language and race played a role in the events that had transpired. ${ }^{93}$ And

87 Stokwe v Member of the Executive Council, Department of Education Eastern Cape Province 20058 BLLR 822 (LC) (hereafter Stokwe).

88 The "language question" in Afrikaans.

$89 \quad$ Stokwe para 4.

90 Stokwe para 11.

$91 \quad$ Stokwe para 12.

92 Du Toit criticised the approach of the court in Stokwe in terms of the principle of subsidiarity, citing the case as an example of the fact that "the courts have remained willing to entertain claims of unfair discrimination by employees brought directly in terms of the Constitution instead of the EEA"; See Du Toit "Prohibition of Unfair Discrimination" 142. 
this the court found to be problematic, in coming to the conclusion that the applicant had indeed been unfairly discriminated against on a number of listed grounds:

\begin{abstract}
On the probabilities, I am of the view that language and race motivated the decision of the SGB ... [T] he applicant was proficient in Afrikaans. The SGB had assumed that, as an African she would not be proficient in Afrikaans. Such stereotyping is an obvious manifestation of bias and prejudice and is a typical form of unlawful discrimination ... From the uncontroverted, clear evidence of the applicant, I must accept that the review panellists were prejudiced against her because of her race, sex, gender, colour and language preference. They discriminated against her on these grounds. Their conduct was unprofessional, appalling and wholly discordant with the values of a democratic constitutional order. ${ }^{94}$
\end{abstract}

Stokwe adds little clarity in respect of how our courts should adjudicate workplace unfair discrimination claims based on language. The court's rather brief finding of unfair discrimination appears to have turned on the cumulative effect of discriminatory conduct which intersected different listed grounds. And the court did not deal with potential justification by the employer of what appeared to be an Afrikaans language proficiency policy (probably on the basis that, as Pillay $\mathrm{J}$ held, the applicant was proficient in Afrikaans, and that the non-appointment of the applicant was due to a racially-prejudiced assumption of a lack of proficiency which was not borne out by the facts). Accordingly, the court did not consider possible inherent requirements of the job defence in this case justifying what appeared to be an Afrikaans proficiency policy. ${ }^{95}$ Ultimately, Stokwe probably is most valuable based on its facts, as an illustration of the intersection and overlapping of listed grounds of discrimination that may occur in practice (and, more specifically, the extant prejudices which may persist around language and race especially).

The second case, Stojce $v$ University of KwaZulu-Natal (hereafter Stojce), ${ }^{96}$ involved a multi-barrelled unfair discrimination claim ${ }^{97}$ brought by a foreignborn university lecturer who had applied for an academic position at a university. One leg of the claim was based on alleged unfair discrimination on the grounds of language, as English was not the applicant's first

94 Stokwe paras 28,29 and 34.

95 The court observed that "The advertisement for the post merely stated that Despatch Primary School was an Afrikaans medium school. Afrikaans was not prescribed as a qualifying requirement for appointment". It is thus unclear from the reported judgment whether, in fact, there was any language proficiency policy in place in the workplace.

96 Stojce $v$ University of KwaZulu-Natal 20073 BLLR 246 (LC) (hereafter Stojce).

97 The applicant alleged unfair discrimination on the grounds of race, language and the unlisted ground of qualification and tertiary teaching and research experience. 
language. The applicant met the job requirements of the post as advertised and was short-listed for an interview. Following the interview, the applicant was informed by letter by the Dean of the relevant faculty that his application had not been successful, citing as reasons that the selection committee felt that he did not have the capacity to teach at tertiary level "as you have insufficient tertiary teaching and research experience", and also that "you have inadequate communication skills in the English language". 98

In respect of the first of these reasons, the respondent averred that:

[a] though the applicant's tertiary teaching experience was stated as being five years, it was not appropriate for South African circumstances for, apart from the classes being large, most of the students came from disadvantaged backgrounds and did not have English as their first language. His undergraduate teaching experience was in his home country, Bulgaria ... [The Dean of the faculty] considered that special skills would be required for teaching large groups of undergraduate students who did not have English as their first language and who came from disadvantaged backgrounds. ${ }^{99}$

In respect of the second of the above-mentioned reasons for the applicant's non-appointment, the interview committee was of the opinion that "notwithstanding the applicant's ability to communicate in English and his commendable effort at speaking a foreign language and conducting research and his undergraduate degree in English, his ability to speak the language was not coherent." 100 The court agreed, finding that the applicant did not communicate clearly and holding that his "grammar was not sufficiently good at times for even the Court to understand him." 101 In the circumstances, Pillay $\mathrm{J}$ held that "respondents, therefore, were entirely justified in refusing to appoint the applicant to the post of lecturer." Earlier, the court had held that the question of inherent requirements of the job did not arise as a potential defence for the employer as the applicant did not put the requirement of speaking English sufficiently coherently as an issue in dispute: "His case was that his English was good enough for the purposes of filling the post and that the respondents did not assess him correctly in this regard."102 The court's finding on this leg of the claim of unfair discrimination therefore appears to have been that the employer was not called upon to justify unfair discrimination. From the facts the court determined that any discrimination (if present at all) was not unfair, due to

Stojce para 7.

Stojce paras 11-12.

Stojce para 13.

Stojce paras 14-15.

Stojce para 4. 
the nature of the job, the applicant's poor proficiency in English and the employer's operational requirements.

While the court here was faced with a language proficiency policy (requiring a threshold level of proficiency in English as the language of tuition at the university) and it would appear that the employer could justify such a policy on the basis of the inherent requirements of the job of a university lecturer, the court, having dismissed a role for the inherent requirements defence on the basis of the applicant's pleaded claim, held that the applicant had failed to prove any discrimination in respect of the respondent's refusal to appoint him. ${ }^{103}$ There was, in the court's view, no reason for the employer to justify the applicant's non-appointment on the basis of inherent requirements, as no case of differentiation or unfair discrimination had been made.

Stojce is of limited value for the present purposes in respect of mapping the future of language-based workplace unfair discrimination claims and how courts should approach them. The court did not investigate the employer's language proficiency requirement (appearing, to an extent, to take judicial notice of the fact that the applicant's apparent proficiency in English fell woefully short of what was required in the university's lecture venues). Nor did it engage with the question of whether such a language proficiency requirement qualified as an inherent requirement of the job, although the court's finding was clearly based on the assumption that it was - the respondent had compared the requirements of the job with the suitability of the candidate to fulfil them, and "that is the essence of the process of filling posts". ${ }^{104}$ In the light of the court's strict approach to the inherent requirements defence (as evidenced more recently in Faris), the sparsity of evaluation in Stojce does little to provide real guidance for future cases involving workplace language proficiency policies and their justification by employers.

More recently, a language-related claim came before the LAC, in De Bruyn. ${ }^{105}$ The appellant, who had been retrenched by a Chinese-owned mining company operating in Africa after his position had allegedly become redundant, challenged his dismissal as automatically unfair on the grounds

\footnotetext{
103 Stojce paras 23 and 28-29.

104 This (what is submitted is a common-sense) approach mirrors that of Jammy AJ in Lagadien v University of Cape Town 200021 ILJ 2469 (LC), by confirming that there is nothing unfairly discriminatory about the normal application of valid and reasonable selection criteria in the process of the selection of a candidate for appointment or promotion (where the outcome of such determination is not arbitrary, capricious or fanciful). 
of unfair discrimination based inter alia on language and nationality/ethnic origin.

The employer, Metorex, had been experiencing dire financial problems in 2015 and the Chinese controlling shareholder in Metorex took the decision to replace the general managers at its mines in the Democratic Republic of the Congo and Zambia with Chinese-speaking nationals. The rationale for the decision was to facilitate better communication by the CEO with general managers on the mines as well as to source investment from Chinese banks and other shareholders in Hong Kong. The Labour Court had rejected the automatically unfair dismissal claim on the basis that the main or dominant cause of the dismissal was the fact that the appellant's post had become redundant, holding that his "selection for retrenchment and nonappointment in the position of acting Deputy CEO ... cannot solely be reduced to his being non-Chinese."

On appeal the LAC held that counsel for the respondent had conceded that the substantial reason for the appointment of a Chinese individual in the senior executive of Metorex, which had made the appellant's position redundant, related to language and culture and that a prime facie case of discrimination had been made out, and the respondent relied on the proportionality-based inherent requirements of the job defence as set out in the Faris ${ }^{106}$ judgment. ${ }^{107}$ The respondent argued that even though there was discrimination it was not unfair and was reasonably justified. The court held that even in light of the acting CEO's concession in evidence that the appellant would not have been retrenched if he had been Chinesespeaking, the "legitimacy of the business rationale for appointing Chinese speaking mine managers and a Chinese speaking CEO could not really be rebutted."108 The court found that "the ability to speak Chinese had essentially become an inherent requirement of the job in order to facilitate direct communications" with the mine managers, banks and shareholders, and that the appellant could not have been reasonably accommodated (holding that "it is hard to contend that the retention of the appellant (merely to accommodate him) ... would not have imposed undue hardship and insurmountable difficulties on Metorex"). ${ }^{109}$

De Bruyn provides confirmation that efficiency of communication may justify a language proficiency policy on the grounds of the inherent requirements

\footnotetext{
106 Faris - see discussion in the text in section 3 above.

107 De Bruyn para 31.

108 De Bruyn para 32.

109 De Bruyn para 38.
} 
of the job (especially when, as on the facts of the case, such a proficiency requirement is coupled with genuine and pressing operational requirements of the employer).

\section{Specific issues regarding language and workplace discrimination}

\subsection{Relevance to the implementation of affirmative action}

Apart from discriminatory policies exposing employers to claims of unfair discrimination, it should be noted that a language policy (such as a "speakEnglish-only" policy, or a language proficiency policy) may constitute a barrier to the employment of persons from designated groups under the EEA or may otherwise negatively impact on the employer's ability to protect or advance such persons. Designated employers are obliged to implement affirmative action measures. These include measures "to identify and eliminate employment barriers ... which adversely affect people from designated groups"110 (such a language policy may constitute such an employment barrier $\left.{ }^{111}\right)$; "measures designed to further diversity in the workplace based on equal dignity and respect of all people"112 (such a policy may be directly contrary to the furtherance of diversity); and "making reasonable accommodation for people from designated groups in order to ensure that they enjoy equal opportunities and are equitably represented in the workforce of an employer"113 (reasonable accommodation ${ }^{114}$ may require flexibility on the part of an employer, for example in the implementation of language proficiency policies).

Also, it should be noted that language may play a role in respect of selection criteria for qualification under an affirmative action policy. In the Equality Court case of Du Preez $v$ Minister of Constitutional Development ${ }^{115}$ language proficiency was identified as a valid and relevant criterion to be considered for the selection of candidates for the position of regional magistrate. An affirmative action policy which focussed on race and gender

\footnotetext{
110 Section 15(2)(a) of the EEA.

111 As recognised in the American context: "English-only rules generally have an adverse impact on protected groups and ... should be closely scrutinized. We also agree that such rules can 'create an atmosphere of inferiority, isolation, and intimidation." Gutierrez v Municipal Court of Southeast Judicial District County of Los Angeles 838 F 2d 1031 (9th Cir 1988) para 20.

112 Section 15(2)(b) of the EEA.

113 Section 15(2)(c) of the EEA.

114 Also see discussion in section 5.3 in the text below.

115 Du Preez v Minister of Justice and Constitutional Development 200627 ILJ 1811 (SE).
} 
to the exclusion of this and other relevant criteria was deemed to be unfairly discriminatory towards an experienced white male candidate. ${ }^{116}$

\subsection{Relevance to testing in the workplace}

The EEA regulates the psychometric testing of employees. Section 8 provides that psychometric testing and "other similar assessments" are prohibited unless the test or assessment "can be applied fairly to employees"117 and "is not biased against any employee or group."118 Educational disparities caused by institutionalised discrimination (as is the case in South Africa) may call into question the extent to which a language proficiency test can be applied fairly to all employees and is not biased against certain employees or groups. ${ }^{119}$ Pre-employment selection tests may be facially neutral but may have a disproportionate impact on certain (race and gender) groups, amounting to indirect unfair discrimination. ${ }^{120}$ In the context of language proficiency testing this may also relate to indirect discrimination on the grounds of culture and ethnic origin.

On a related note, language proficiency testing linked with job requirements (and job descriptions as contained in advertisements) such as "excellent verbal and written communication skills" may not only implicate language as a basis for potential unfair discrimination, it may also indirectly discriminate on the grounds of disability (for example, in the case of dyslexic applicants). Employers must proceed with care when choosing, designing and implementing such testing or job requirements.

\subsection{Reasonable accommodation}

The EEA defines "reasonable accommodation" as "any modification or adjustment to a job or to the working environment that will enable a person from a designated group to have access to or participate or advance in employment."121 The concept of reasonable accommodation is well-known in international instruments as well as in domestic anti-discrimination legislation in various jurisdictions (specifically in the USA's Americans with Disabilities Act). ${ }^{122}$ The concept is closely linked to the employer's inherent

\footnotetext{
116 See, specifically, Du Preez v Minister of Justice and Constitutional Development 200627 ILJ 1811 (SE) para 38.

Section $8(b)$ of the EEA.

Section 8(c) of the EEA.

Basson "Employment Testing" 219.

Basson "Employment Testing" 219.

Section 1 of the EEA.

Americans with Disabilities Act, 1990 (42 USC § 12101).
} 
requirements of the job defence to claims of unfair discrimination: Where an employee can be reasonably accommodated (without placing undue hardship on the employer) in order to be able to perform the job, then the presence of the relevant ground of discrimination cannot be viewed as constituting an inherent requirement which would justify the employer's differential treatment of the employee in the circumstances.

It is primarily in the context of disability that the concept of reasonable accommodation has obtained traction, in order to ensure that disabled persons are accommodated in order to be able to be engaged in productive work. But the EEA also identifies reasonable accommodation as a form of an affirmative action measure, stating that affirmative action measures implemented by designated employers must include "making reasonable accommodation for people from designated groups in order to ensure that they enjoy equal opportunities and are equitably represented in the workforce of an employer." ${ }^{123}$ The mention of persons from designated groups as the beneficiaries of reasonable accommodation in both the Act's definition of the term as well as under the affirmative action provisions shows that accommodation must not only be made on the grounds of disability (one of the designated groups), but also on the grounds of race and sex.

This accords with the Constitutional Court's understanding of the scope of the duty of reasonable accommodation as also encompassing other listed grounds of unfair discrimination. ${ }^{124}$ Accordingly, employers who impose potentially unfair discriminatory workplace language policies must consider the role of reasonable accommodation of an employee's language choice or use.

To date our courts have not extensively considered reasonable accommodation in this context. In Stojce the Labour Court found that the claimant's language proficiency was simply below par, and that the employer was completely justified to refuse to appoint a person as a university lecturer whose English was incoherent. In Stokwe the same court found that the claimant was proficient in Afrikaans, which seems to preclude the need for any accommodation on the facts. In De Bruyn the LAC very briefly dealt with the issue in holding that the retention of the redundant employee would have imposed "undue hardship and insurmountable

\footnotetext{
123 Section 15(2)(c) of the EEA.

124 See Pillay paras 73-75.
} 
difficulties" on the employer, which was experiencing significant economic problems.

In the case of language proficiency policies, it seems that the reasonable accommodation of an employee who lacks the required level of proficiency would be closely linked to the employer's duty to apply inherent job requirements in a rational and proportional manner. Mention was made earlier of the fact that employers need to be circumspect in respect of testing for language proficiency and also in respect of applying blanket bans on employees who are not proficient across the whole workplace or organisation of the employer. What would be reasonable would depend on the required level of proficiency in order to perform the job. An employee who needs to communicate effectively with customers or co-workers can probably be accommodated if the cause for the employer's concern relates simply to unwanted accents or dialects, while an employee experiencing the difficulties experienced by the claimant in Stojce ("His grammar was not sufficiently good at times for even the Court to understand him...") and in De Bruyn would have less scope to claim that an employer can and should make reasonable accommodation in order to modify or adapt the job or working environment. At the more extreme end of the spectrum, and in the light of the qualification that reasonable accommodation does not require undue hardship for the employer, it is debatable whether employers might be called on to invest in technological aids in order to accommodate an incoherent employee. In the case of an employee with a speech disability this may be the case, but it is doubtful that a court would impose such a burden on an employer faced with an employee whose language use is below the required standard (e.g. due to the poor use of grammar, poor pronunciation or other deficiencies of language). Ultimately, it is a question of proportionality. ${ }^{125}$

Also, as mentioned earlier, an employer may more easily be able to justify language proficiency as an inherent job requirement where a certain level of proficiency may be externally prescribed for the relevant job (again, consider the examples of English language proficiency levels for pilots and air traffic controllers, or proficiency standards prescribed in the teaching profession). Where there exists such an externally-imposed proficiency standard an employer would likewise be less likely to be forced to accommodate a non-compliant employee (and any form of accommodation

125 As Langa CJ observed in Pillay para 77 that a "... reasonable accommodation is, in a sense, an exercise in proportionality that will depend intimately on the facts." Also see Bernard 2014 PELJ 2880, with reference to POPCRU para 43. 
which might, for example, expose the employer to risks of public safety or to contravention of the relevant law would undoubtedly amount to undue hardship on the employer). It is fruitless to speculate on the parameters of the application of reasonable accommodation in respect of language in the absence of a specific set of facts, and one will have to await guidance from the courts in any possible future cases involving this specific aspect.

\title{
6.4 Harassment (and employer liability)
}

The EEA in section 6(3) provides that "... harassment of an employee is a form of unfair discrimination and is prohibited on any one, or a combination of grounds of unfair discrimination listed in [section 6(1) of the Act]". Apart from the fact that an employer may engage in harassing conduct towards an employee based on language, the Act also prohibits harassment on any such grounds by fellow employees. While "harassment" is not defined in the EAA, much may be gleaned from the definition of harassment contained in section 1 of PEPUDA:

\begin{abstract}
[U]nwanted conduct which is persistent or serious and demeans, humiliates or creates a hostile or intimidating environment or is calculated to induce submission by actual or threatened adverse consequences and which is related to (a) sex, gender or sexual orientation; or (b) a person's membership or presumed membership of a group identified by one or more of the prohibited grounds or a characteristic associated with such group.
\end{abstract}

Mention was made earlier of the role of language in respect of identity. Language as a characteristic associated with an ethnic, racial or cultural group, for example, could serve to ground a claim for harassment (for example, derogatory statements made around the water cooler by fellow employees in respect of an employee's use of vernacular or peculiar dialects). Apart from potential language-based unfair discrimination by employers against employees, it should be noted that employers may also be vicariously liable in terms of section 60 of the EEA for acts of unfair discrimination or harassment by employees against other employees.

Although the Labour Court has held that an employer cannot be held liable in terms of section 60 for unfair discrimination (and, it is assumed, harassment) of an employee by a customer of the employer's business, ${ }^{126}$ it is possible that delictual liability under the common law ${ }^{127}$ may follow. ${ }^{128}$

\footnotetext{
126 Shoprite Checkers (Pty) Ltd v Samka 20189 BLLR 922 (LC) (in that case, unfair discrimination on the grounds of race).

127 See Media 24 Ltd v Grobler 20053 All SA 297 (SCA) (in the context of sexual harassment).

128 See Rossouw and Nana 2018 http://www.mondaq.com/southafrica/ $\mathrm{x} / 729920 /$ Discrimination+Disability+Sexual+Harassment/Can+An+Employer+Be+H
} 
Also, as noted earlier, customer conduct and/or preferences in respect of the use of language by an employee will in all likelihood not be viewed as justification of unfair discrimination on the grounds of inherent requirements of the job. ${ }^{129}$

\section{Concluding thoughts}

It may be surprising that in South Africa, with its eleven official languages and significant cultural and ethnic diversity, language has not played a more prominent role in our case law on workplace discrimination. This is so, specifically, also in the light of the fact that, as mentioned before, the express listing of "language" as a prohibited ground in the constitutional equality right and the employment legislation means that - compared to claimants in most of the other jurisdictions mentioned in this article - South African claimants have more direct recourse to "language" as a discrete ground (and to the presumption of unfairness under section 9(2) of the Bill of Rights, section 6(1) of the EEA and the Harksen test).

Our social and political discourse is frequently preoccupied with hate speech and the like, and for lawyers this involves careful consideration of the limits of freedom of expression. But apart from what people say, our courts have to date been relatively untroubled in respect of considering how people say things and the language they use in exercising their freedom of expression. Race discrimination (and just plain racism) often features in this discourse around expression. But prejudice and discrimination can also occur on the grounds of the language we (choose to) use, and may have significant implications in respect of the dignity of a potential claimant.

In the employment context it may be that the very fact of our significant degree of linguistic diversity is a prime reason why language discrimination claims have largely been absent from the workplace discrimination landscape to date. When workers from a range of different backgrounds (and who speak very different languages) are thrown together in the workplace it might be a natural response to accept the need for (linguistic) uniformity. English as common denominator serves to ensure the smooth running of our workplaces for the most part, and this may mean that employer policies that may be suspect in other jurisdictions are perceived to be less so here. Necessity may have bred a widespread laissez-faire attitude towards the hegemony of the English language (the most obvious

eld + Liable+For+Racial+Discrimination+Towards+An+Employee+By+One+Of+lts+

Customers.

129

See section 3.1 in the text above. 
choice for the most ubiquitous and practical of our official languages, which manages largely to cut across social, ethnic and cultural groupings). It may be that, as a result, things like English proficiency policies in the workplace are not viewed as inherently suspicious or potentially prejudicial.

Another reason may be the fact that we are also such a significantly multilingual society. As Moseneke DCJ put it in the Ermelo High School case, section 6 of the Bill of Rights "warrants and widens the span of our official languages from a partisan pair to include nine indigenous languages which for long have jostled for space and equal worth." 130 Most learners in our schools are second-language English speakers who are taught mostly in English as their second language. We may be socialised from a very young age into acceptance of English as the "language of real life". When compared to the United States and its largely monolingual (Englishlanguage) population, it seems intuitive that the relative prevalence of language-based challenges to workplace policies there by minority groups has not transpired here at home. Afrikaans, the "language of the oppressor" in our pre-constitutional dispensation, ${ }^{131}$ is rightly or wrongly largely being phased out in our workplaces. English carries a lot less historical and pejorative baggage, and may thus be more immune to resistance from the speakers of other languages.

Yet, even in light of the above, developments in our law on workplace discrimination and the scope of protection afforded to potential claimants may see a change to this trend in future. The relatively new-found unfair discrimination jurisdiction of the Commission for Conciliation, Mediation and Arbitration (CCMA), coupled with the extension of the grounds for unfair discrimination (with the addition of "or any other arbitrary ground" in section 6(1) of the EEA) through the 2014 legislative amendments may hold the potential for more movement on this front in future. As observed in this article, discrimination on the basis of or linked to language may often implicate other listed grounds (such as race, ethnicity, culture and the like) as well as possible unlisted and arbitrary grounds. This may hold the potential for an increase in language-based unfair discrimination claims, and this ground may be a potential future growth industry for claimants and lawyers alike.

130 Head of Department: Mpumalanga Department of Education v Hoërskool Ermelo 20102 SA 415 (CC) para 47.

131 For some brief thoughts on the historical role of Afrikaans, see AfriForum $v$ University of the Free State 20182 SA 185 (CC) paras 2-3. 


\section{Bibliography}

\section{Literature}

Ackerman Cross-Cultural Negotiations

Ackerman GR (ed) Cross-Cultural Negotiations and Dispute Resolution: Readings and Cases (University Publishing Solutions East Brunswick 2003)

ACLU Northern California Language Discrimination

American Civil Liberties Union Foundation of Northern California Language Discrimination: Your Legal Rights (ACLU of Northern California San Francisco 2002)

Ainsworth 2010 Seattle $J$ for Soc Just

Ainsworth $\mathrm{J}$ "Language, Power and Identity in the Workplace: Enforcement of 'English-Only' Rules by Employers" 2010 Seattle J for Soc Just 233-258

Basson "Employment Testing"

Basson A "Employment Testing" in Strydom EML (ed) Essential Employment Discrimination Law (Juta Cape Town 2004) 189-227

Baugh "Linguistic Profiling and Discrimination"

Baugh J "Linguistic Profiling and Discrimination" in Garcia O, Flores N and Spotti M (eds) The Oxford Handbook of Language and Society (Oxford University Press Oxford 2017) 349-368

Bernard 2014 PELJ

Bernard R "Reasonable Accommodation in the Workplace: To Be or Not to Be?" 2014 PELJ 2869-2891

Cavico, Muffler and Mujtaba 2013 JIBCS

Cavico FJ, Muffler SC and Mujtaba BG "Language Diversity and Discrimination in the American Workplace: Legal, Ethical and Practical Considerations for Management" 2013 JIBCS 20-58

Colon 2002 Yale L \& Pol'y Rev

Colon M "Line Drawing, Code Switching, and Spanish as Second-Hand Smoke: English-Only Workplace Rules and Bilingual Employees" 2002 Yale L \& Pol'y Rev 227-267

Currie and De Waal Bill of Rights Handbook

Currie I and De Waal J The Bill of Rights Handbook $6^{\text {th }}$ ed (Juta Cape Town 2013) 
Du Toit "Prohibition of Unfair Discrimination"

Du Toit D "The Prohibition of Unfair Discrimination: Applying Section 3 (d) of the Employment Equity Act 55 of 1998" in Dupper OC and Garbers C (eds) Equality in the Workplace: Reflections from South Africa and Beyond (Juta Cape Town 2009) 139-158

Garbers 2019 CLL

Garbers C "The Meaning of 'Any Other Arbitrary Ground' of Discrimination: The Battle for the Soul of Anti-Discrimination Law" 2019 CLL 51-66

Grogan Employment Rights

Grogan J Employment Rights $3^{\text {rd }}$ ed (Juta Cape Town 2019)

Munro 2003 TESL Canada Journal

Munro MJ "A Primer on Accent Discrimination in the Canadian Context" 2003 TESL Canada Journal 38-51

Munson 2007 Language and Speech

Munson B "The Acoustic Correlates of Perceived Masculinity, Perceived Femininity, and Perceived Sexual Orientation" 2007 Language and Speech 125-142

\section{Paz 2014 EJIL}

Paz M "The Tower of Babel: Human Rights and the Paradox of Language" 2014 EJIL 473-496

Prinsloo and Huysamen 2018 LDD

Prinsloo $M$ and Huysamen E "Cultural and Religious Diversity: Are They Effectively Accommodated in the South African Workplace?" 2018 LDD 2638

Ontario Human Rights Commission Policy on Discrimination and Language Ontario Human Rights Commission Policy on Discrimination and Language (Ontario Human Rights Commission Toronto 1996, amended in 2009)

Schoeman 2018 Corporate Report

Schoeman C "Unconscious Bias, Latent Discrimination and Real Consequences" 2018 The Corporate Report 3-7

Stoter 2008 Vill L Rev

Stoter RS "Discrimination and Deference: Making a Case for the EEOC's Expertise with English-Only Rules" 2008 Vill L Rev 595-635 
Van Niekerk and Smit Law@Work

Van Niekerk A and Smit N Law@Work $3^{\text {rd }}$ ed (LexisNexis Durban 2014)

Case law

Canada

Espinoza v Coldmatic Refrigeration of Canada Inc et al (Ont Bd of Inq) (unreported) inquiry file number 93-0043 and decision 95-013 of 31 March 1995

\section{South Africa}

AfriForum v University of the Free State 20182 SA 185 (CC)

De Bruyn v Metorex (Pty) Ltd 202110 BLLR 979 (LAC)

Department of Correctional Services v Police and Prisons Civil Rights Union 201334 ILJ 1375 (SCA)

Du Preez v Minister of Constitutional Development 200627 ILJ 1811 (SE)

Grütter v Lombard 20074 SA 89 (SCA)

Harksen $v$ Lane 19981 SA 300 (CC)

Head of Department: Mpumalanga Department of Education v Hoërskool Ermelo 20102 SA 415 (CC)

Hoffmann v South African Airways 20011 SA 1 (CC)

IMATU v City of Cape Town 200526 ILJ 1404 (LC)

In Re Certification of the Constitution of the Republic of South Africa 1996 4 SA 744 (CC)

Jansen van Vuuren v SA Airways (Pty) Ltd 201334 ILJ 1749 (LC)

Khumalo v Holomisa 20025 SA 401 (CC)

Lagadien v University of Cape Town 200021 ILJ 2469 (LC)

Lourens $v$ Speaker of the National Assembly of Parliament 20162 All SA 340 (SCA)

MEC for Education: Kwazulu-Natal v Pillay 20081 SA 474 (CC) 
Media 24 Ltd v Grobler 20053 All SA 297 (SCA)

Naidoo v Parliament of the Republic of South Africa 202010 BLLR 1009 (LAC)

Shoprite Checkers (Pty) Ltd v Samka 20189 BLLR 922 (LC)

South African Airways (Pty) Ltd v GJJVV 20148 BLLR 748 (LAC)

Stojce v University of KwaZulu-Natal 20073 BLLR 246 (LC)

Stokwe $v$ Member of the Executive Council, Department of Education Eastern Cape Province 20058 BLLR 822 (LC)

TDF Network Africa (Pty) Ltd v Faris 20192 BLLR 127 (LAC)

\section{United States of America}

Gutierrez v Municipal Court of Southeast Judicial District County of Los Angeles 838 F 2d 1031 (9th Cir 1988)

\section{Legislation}

\section{Australia}

Racial Discrimination Act, 1975

New Zealand

Human Rights Act, 1993

\section{South Africa}

Constitution of the Republic of South Africa, 1996

Employment Equity Act 55 of 1998

Labour Relations Act 66 of 1995

National Credit Act 34 of 2005

Pan South African Language Board Act 59 of 1995

Pan South African Language Board Amendment Act 10 of 1999

Promotion of Equality and Prevention of Unfair Discrimination Act 4 of 2000 
Use of Official Languages Act 12 of 2012

\section{United Kingdom}

Equality Act, 2010

Immigration Act, 2016

\section{United States of America}

Americans with Disabilities Act, 1990 (42 USC § 12101)

Civil Rights Act, 1964

\section{Government publications}

GN R425 in GG 35398 of 1 June 2012 (Civil Aviation Regulations, 2011)

GN 111 in GG 38487 of 19 February 2015 (Revised Policy for the Minimum Requirements for Teacher Education Qualifications)

\section{Internet sources}

Australian Human Rights Commission date unknown https://www.humanrights.gov.au/quick-guide/12060

Australian Human Rights Commission date unknown Quick Guide https://www.humanrights.gov.au/quick-guide/12060 accessed 9 September 2021

Britannica date unknown https://www.britannica.com/topic/language Britannica date unknown Language https://www.britannica.com/topic/ language accessed 9 September 2021

Collins English Dictionary date unknown https://www.collinsdictionary.com/dictionary/english/language Collins English Dictionary date unknown Language https://www.collinsdictionary.com/dictionary/english/language accessed 9 September 2021

Dictionary.com date unknown https://www.dictionary.com/browse/ language\#

Dictionary.com date unknown Language https://www.dictionary.com/ browse/language\# accessed 9 September 2021 
Dictionary.com date unknown https://www.dictionary.com/browse/signlanguage? $\mathrm{s}=\mathrm{t}$

Dictionary.com date unknown Sign Language https://www.dictionary. com/browse/sign-language?s=t accessed 9 September 2021

Finbond date unknown https://www.finbondplatinum.co.za/vision-andmission

Finbond date unknown Vision and Mission https://www.finbond platinum.co.za/vision-and-mission accessed 9 September 2021

FNB date unknown https://www.rmbprivatebank.com/downloads/RMB PrivateBank/evolve/legal/FirstRandLanguageProposal.pdf

First National Bank date unknown FNB Language Policy https://www.rmbprivatebank.com/downloads/RMBPrivateBank/evolve/legal /FirstRandLanguageProposal.pdf accessed 9 September 2021

Foy 2021 https://www.insurancejournal.com/news/national/2012/12/04/ 272632.htm\#Foy P 2021 More Workers Claiming Employment Discrimination Over Language, Accents https://www.insurance journal.com/news/national/2012/12/04/272632.htm\# accessed 9 September 2021

Milsom 2016 https://www.cloisters.com/the-immigration-act-and-thefluency-duty-for-public-sector-workers-speaking-in-tongues/

Milsom C 2016 The Immigration Act and the "Fluency Duty" for Public Sector Workers: Speaking in Tongues? https://www.cloisters.com/theimmigration-act-and-the-fluency-duty-for-public-sector-workers-speakingin-tongues/ accessed 9 September 2021

New Zealand Human Rights Commission date unknown https://www.hrc.co.nz/how-we-can-help/faqs/english-language-onlyworkplace/

New Zealand Human Rights Commission date unknown English Only in the Workplace https://www.hrc.co.nz/how-we-can-help/faqs/english-languageonly-workplace/ accessed 9 September 2021

Rossouw and Nana 2018 http://www.mondaq.com/southafrica/x/729920/ Discrimination+Disability+Sexual+Harassment/Can $+\mathrm{An}+$ Employer+Be+He Id+Liable+For+Racial+Discrimination+Towards+An+Employee+By+One+ Of+Its+Customers

Rossouw H and Nana F 2018 Can an Employer be Held Liable for Racial Discrimination Towards an Employee by One of Its Customers? http://www.mondaq.com/southafrica///729920/Discrimination+Disability+S 
exual+Harassment/Can+An+Employer+Be+Held+Liable+For+Racial+Disc rimination+Towards $+\mathrm{An}+$ Employee+By+One+Of+Its+Customers accessed 9 September 2021

US Equal Employment Opportunity Commission date unknown https://www.eeoc.gov/laws/types/nationalorigin.cfm

US Equal Employment Opportunity Commission date unknown National Origin Discrimination https://www.eeoc.gov/laws/types/nationalorigin.cfm accessed 9 September 2021

\section{List of Abbreviations}

ACLU

CEO

CCMA

CLL

EEA

EJIL

FNB

JIBCS

LAC

LDD

LRA

PANSALB

PELJ

PEPUDA

SCA

Seattle $\mathrm{J}$ for Soc Just

SGB

UK

USA

Vill L Rev

Yale L \& Pol'y Rev
American Civil Liberties Union

Chief Executive Officer

Commission for Conciliation, Mediation and

Arbitration

Contemporary Labour Law

Employment Equity Act 55 of 1998

European Journal of International Law

First National Bank

Journal of International Business and Cultural Studies

Labour Appeal Court

Law, Democracy and Development

Labour Relations Act 66 of 1995

Pan South African Language Board

Potchefstroom Electronic Law Journal

Promotion of Equality and Prevention of

Unfair Discrimination Act 4 of 2000

Supreme Court of Appeal

Seattle Journal for Social Justice

School Governing Body

United Kingdom

United States of America

Villanova Law Review

Yale Law and Policy Review 